\title{
Breeding Crops for Organic Agriculture: A Review
}

\author{
Shailja Sharma and Sanchit Thakur* \\ Department of Crop Improvement, CSKHPKV, Palampur-176062, India \\ *Corresponding author
}

\section{A B S T R A C T}

\section{Keywords \\ Breeding crops, Organic agriculture \\ Article Info \\ Accepted: \\ 10 October 2018 \\ Available Online: \\ 10 November 2018}

In this review article, we describe various underlying principles and techniques behind breeding crops for organic agriculture. As we know, according to standards of organic agriculture, genetic engineering or its use in any which way is restricted. Basically organic agriculture is based on the underlying principles of health, farmers, ecology and care. The norms that derive organic agriculture are product oriented. Most of the varieties used for organic agriculture are derived from conventional plant breeding which are input responsive. Thus, there is a need to breed varieties especially for organic agriculture to unlock its full potential.

\section{Introduction}

Organic farming or biodynamic farming is quite different from conventional or nonorganic farming in respect that is aims to increase dependence on natural biological systems. In non-organic agriculture, such systems are not important as it is highly focused on dependency of crops on external and synthetic inputs and exploitation of natural biological systems at all levels starting from a sub-gene level.

Thus, difference in varieties suitable in both two approaches is very different. Due to various constraints of non-organic breeding programmes, the varieties developed cannot be able to unlock full potential of organic agriculture. So, there is a need to develop varieties which are specifically bred under organic conditions. Such varieties can ensure quality along with yield in organic section.

\section{General guidelines for organic plant breeding methodology}

General guidelines for organic plant breeding methodology which are currently accepted can be summarized in the following points:

The main aim of organic plant breeding should be to develop those cultivars that unlock full potential of organic farming respecting natural biological systems i.e. should be based on fertile plants which can maintain viable relation with living soil and respects barriers that exist in nature.

Clearly, methods that do not respect plant integrity especially those that operates below 
cell level are prohibited e.g. GM, CMS hybridization with restorer gene, protoplast fusion etc.

If $\mathrm{F} 1$ hybrid is fertile and can easily propagate under organic conditions, then only the F1 hybrid production is permitted.

DNA marker assisted selection can be allowed only if GMOs and radiations are not involved in marker production.

Meristem culture can be used for virus elimination. As patenting of material leads to restrictions on its free exchange among breeders and farmers. So, it is not allowed.

\section{Breeding objectives}

Breeding objectives in case of organic agriculture are quite different in range and level as well as in priority from non-organic agriculture despite of various overlaps like yield, disease resistance etc. Weed competitiveness is important in case of organic agriculture which is not the priority in non- organic agriculture. Yield has a comparatively lower priority in organic breeding as compared with conventional agriculture.

\section{A vision on organic plant breeding}

The vision of organic plant breeding is based on principles of ecology, health, care and farmers.

Vision on organic plant breeding is covered in following topics-

\section{Environmentally friendly and people friendly organic agriculture}

Without the use of synthetic chemicals, fertilizers, pesticides, herbicides, growth hormones etc, organic producers should try to achieve optimal economic yield without exhausting natural resources. Organic farming should not only be environment friendly but should be regarded as a best source of wholesome food. When people were asked why organic food is better for them, most of the people said that organic foods are free from harmful chemicals and residues (De Waart, 1998). Organic food should not only mean absence of chemicals but should provide a quality food. Most of the varieties used for organic farming are bred for non-organic farming so there is a need to develop varieties for organic section to improve quality and yield (Fig. 1).

\section{Various parties in organic breeding}

Mainly three parties i.e. farmers (producers), trade and industry (manufacturers) and breeders (gene banks, seed companies etc) are involved in production starting from breeder to consumer. Farmers are dependent on organic fertilizers and $\mathrm{N}$-fixing mineral inputs. Also, farmers have knowledge of which variety is good and is also aware of local circumstances, conditions and limitations. On the other hand, trade and industry demands products that meet the required standard. Mostly consumers required unprocessed food free from chemicals and synthetic additives. Lastly, breeders should maintain and develop varieties in a sustainable manner taking care the principles of organic agriculture. Varieties should be bred and tested under organic conditions so that they can provide good yield even in low input conditions. Most important conviction which unite these three links in production chain is that these all should respect wholeness of living entity.

\section{Criteria at farm level}

As far as organic agriculture is concerned most principle pertain to management of farm. Natural self-regulation, agro-biodiversity and 
closed production cycles forms the basis of organic production. Organic farms should have to be closed nutrient cycles to reduce closer to minimum. This can be done by uniting aerable and livestock production, either by forming mixed farming systems in farms or by collaboration between farms that are specialized according to Partner farm concept (Baars, 1998; Van der Burgt et al., 1999) Soil fertility plays an important part in self-regulatory agro-ecosystem. Effective organic manure applications, biological $\mathrm{N}$ fixation and good crop rotation scheme are must for ensuring good soil fertility. Lastly, greater the diversity of crops or the organisms on the farms, more will be the natural selfregulatory capacity of the farm.

\section{Criteria at plant level}

At the plant level we deal with three criterianatural reproductive ability, ability to adapt independently to environment and genetic diversity. Side by side respecting species characteristics and natural species authenticity. Natural reproductive ability means varieties should have a potential to carry out reproduction in natural conditions which automatically excludes any of the steps like fertilization which is carried out in laboratories.

Varieties which are grown organically should be resilient and flexible as far as the environment is concerned. They should be adapted to the seasonal in situ fluctuations in availability of nutrients in soil. Nutrient mobilization of plant (Scheller, 1988) is a combination of more efficient $\mathrm{N}$ uptake and deeper rootage there should be a balance between varieties that are bred for a particular environment and varieties that are bred specially for particular conditions. As synthetic herbicides are not allowed in organic farming, so crop must have vigour and competitiveness to suppress weeds at earlier stages of growth. Weed suppressive ability is an important criteria in organic plant breeding (Muller, 1998). Varieties should also have resistance to diseases and plagues. Absolute monogenetic resistance is not desirable in organic production as it can be easily broken so polygenic resistance is the need of the hour.

Many factors like plant structure, growth pattern and heterozygosity all contribute to resistance, tolerance and restorative ability. So, we can say that use of heterozygous varieties is more beneficial than a mix of homozygous varieties in field. Genetic diversity in crop species should be fully utilized side by side is respecting natural species authenticity. The corporate mergers are also contributing to the narrowing the genetic basis of plant breeding programmes (Haselmans, 1998). Also too strong focus on quantity or yield should not result in ignoring quality of crops or it's nutritional value. Ability to mature and harmony in plant's gestalt are important factor's pertaining to food quality (Bauer, 1988) (Fig. 1; Table 1 and 2).

\section{Socio economic criteria}

Conventional plant breeding has many disadvantages as it is mainly focused on development of standard varieties which do not take into consideration organic farming conditions. These limitations are institutional, technical, economical and conceptual in nature (Hardon et al., 1993).

Organic plant breeding should be interactive as compared to conventional breeding so that farmer's needs along with industrial or trade requirements are given importance and making full use of all the wisdom and experience of the farmer. Breeding system involves selecting varieties in natural conditions in which farmer can play important role. This approach is also known as participatory plant breeding. 
Table.1 The criteria of organic plant breeding, on the basis of principles of organic agriculture

\begin{tabular}{|c|c|c|}
\hline Farm level & Plant level & Socio-economic level \\
\hline - closed production cycles & - natural reproductive ability & $\begin{array}{l}\text { - close interaction between } \\
\text { farmers, trade and industry } \\
\text { and breeders }\end{array}$ \\
\hline - natural self-regulation & $\begin{array}{l}\text { - ability to adapt indepen- } \\
\text { dently to environment }\end{array}$ & $\begin{array}{l}\text { regulations incorporating } \\
\text { organic principles }\end{array}$ \\
\hline $\begin{array}{l}\text { - rich variety of organisms: } \\
\text { agro-biodiversity }\end{array}$ & $\begin{array}{l}\text { - genetic diversity with } \\
\text { respect for natural species } \\
\text { authenticity and species } \\
\text { characteristics }\end{array}$ & $\begin{array}{l}\text { - cultural diversity: many different } \\
\text { breeding programmes }\end{array}$ \\
\hline
\end{tabular}

Source: Lammerts van Bueren, E.T., Hulscher, M., Jongerden, J., Ruivenkamp, G.T.P., Haring, M., van Mansvelt, J.D. and den Nijs, A.M.P., 1999. Sustainable organic plant breeding: Final report-a vision, choices, consequences and steps.

Table.2 A summary of breeding techniques and their suitability in plant breeding

\begin{tabular}{|c|c|c|c|c|}
\hline & $\begin{array}{l}\text { Variation induction } \\
\text { techniques }\end{array}$ & Selection techniques & $\begin{array}{l}\text { Maintenance and } \\
\text { propagation }\end{array}$ & Substances \\
\hline $\begin{array}{l}\text { Suitable for } \\
\text { organic } \\
\text { breeding }\end{array}$ & $\begin{array}{l}\text { combination breeding } \\
\text { crossing varieties } \\
\text { bridge crossing } \\
\text { repeated backcrossing } \\
\text { hybrids with fertile F1 } \\
\text { temperature treating } \\
\text { cutting style } \\
\text { grafting style } \\
\text { unradiated mentor pollen }\end{array}$ & $\begin{array}{l}\text { mass selection } \\
\text { pedigree selection } \\
\text { site-determined selection } \\
\text { change in surroundings } \\
\text { change in sowing time } \\
\text { ear bed method } \\
\text { test crosses } \\
\text { indirect selection } \\
\text { DNA diagnostics }\end{array}$ & $\begin{array}{l}\text { generative propagation } \\
\text { vegetative propagation: } \\
\text { partitioned tubers } \\
\text { scales, husks, partitioned } \\
\text { bulbs } \\
\text { brood buds, bulbils } \\
\text { offset bulbs, etc. } \\
\text { layer, cut and graft shoots } \\
\text { rhizomes }\end{array}$ & \\
\hline $\begin{array}{l}\text { Not suitable, } \\
\text { but to be } \\
\text { provisionally } \\
\text { allowed }\end{array}$ & $\begin{array}{l}\text { embryo culture } \\
\text { ovary culture } \\
\text { in vitro pollination }\end{array}$ & in vitro selection & $\begin{array}{l}\text { anther culture } \\
\text { microspores culture } \\
\text { meristem culture } \\
\text { micro-propagation } \\
\text { somatic embryogenesis }\end{array}$ & $\begin{array}{l}\text { silver thiosulfate } \\
\text { silver nitrate } \\
\text { growth stimulants and } \\
\text { colchicine (and } \\
\text { related substances) }\end{array}$ \\
\hline $\begin{array}{l}\text { Not suitable, } \\
\text { but to be banned } \\
\text { immediately }\end{array}$ & $\begin{array}{l}\text { cms hybrids without } \\
\text { restorer genes } \\
\text { protoplast fusion } \\
\text { radiated mentor pollen } \\
\text { artificial mutation induction } \\
\text { genetic modification }\end{array}$ & & & \\
\hline
\end{tabular}

Source: Lammerts van Bueren, E.T., Hulscher, M., Jongerden, J., Ruivenkamp, G.T.P., Haring, M., van Mansvelt, J.D. and den Nijs, A.M.P., 1999. Sustainable organic plant breeding: Final report-a vision, choices, consequences and steps. 
Fig.1 The three main parties of organic plant breeding chain

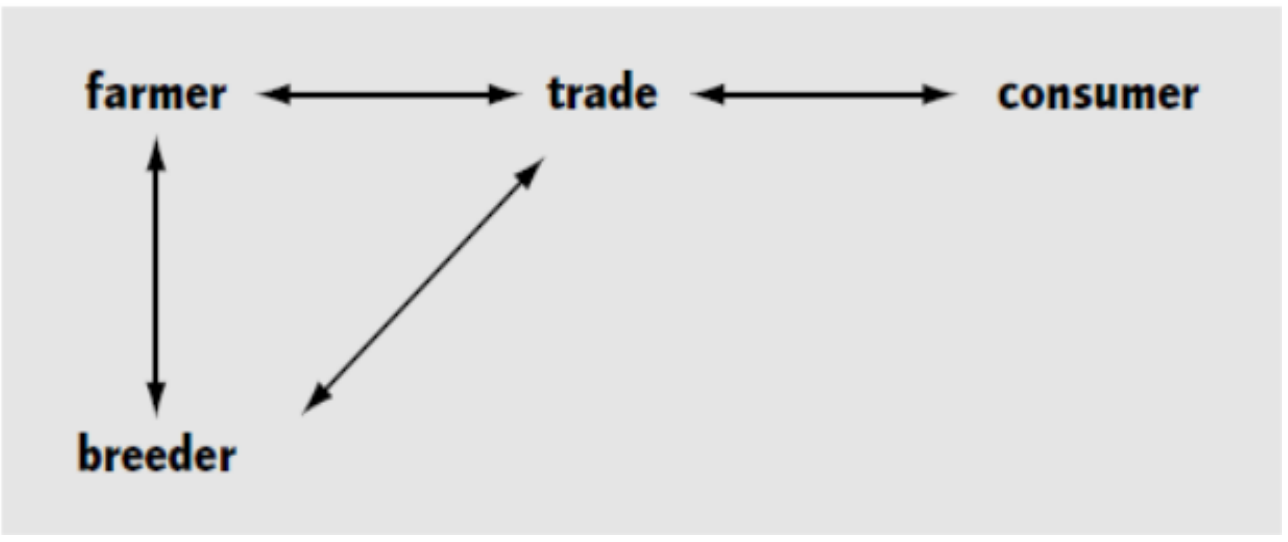

Fig.2 A flow chart of organic plant breeding and propagation

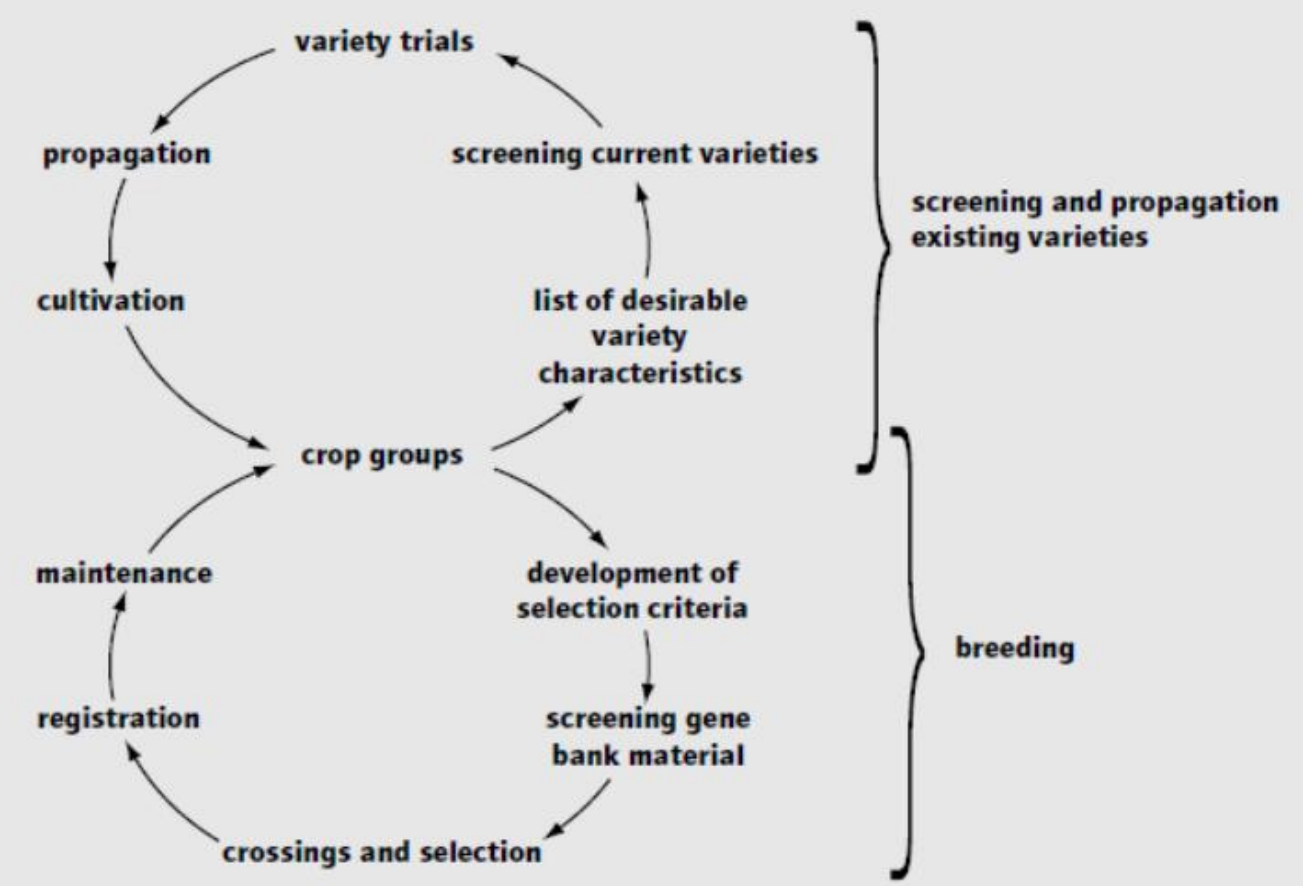

Source: Lammerts van Bueren, E.T., Hulscher, M., Jongerden, J., Ruivenkamp, G.T.P., Haring, M., van Mansvelt, J.D. and den Nijs, A.M.P., 1999. Sustainable organic plant breeding: Final report-a vision, choices, consequences and steps.

\section{Choosing breeding techniques}

\section{Techniques at plant and crop level}

When hybrids are used, $\mathrm{F}_{1}$ progeny should not be propagated by means of generative propagation rather should be maintained by repeatedly crossing parent lines. Using hybrids in case of organic agriculture can only be justified in case of following:

Unavailability of comparable seed propagating varieties.

F1 can be used as a cross parent and is sterile. 
Homozygous lines having sufficient vigour so that they can be propagated easily.

\section{Techniques at cell level}

Breeding techniques at cell level fall in grey category between the accepted and not accepted ones. As we know that cell is the smallest living entity and cell techniques could be used without violating organic principles to work only with living entities.

On the other hand, farmers only deal at plant level which is smallest unit in relation to environment. Therefore, use of techniques at cell level is still a controversy.

\section{Protoplast Fusion}

This technique is also rejected in organic plant breeding because this is only applicable when two species differs too much that they could not be crossed under natural conditions which is against the principles and ethics of organic plant breeding.

\section{Cytoplasmic male sterility}

Organic agriculture respect use of techniques that interfere with plant's natural reproductive ability. As if now the sector particularly opposes CMS hybrids that are used without having restorer genes.

Artificial induction- According to vision of organic plant breeding, direct manipulations at DNA level is undesirable. Thus, we can say artificial induction like mutation in DNA by radiation or chemical mutagens etc is unsuitable in this sector.

\section{Techniques at DNA level}

Genetic modifications are absolutely prohibited or techniques at DNA level are strictly prohibited.

\section{Breeding}

Varieties that are considered to be suitable for organic agriculture would not need to be bred for organic farming straightaway. For other varieties, there should be an effort to breed for organic agriculture as soon as possible.

\section{Genetic sources}

As list of available gene bank stocks should be prepared taking into consideration the characteristics that are required for organic farming. In this way, required genetic stocks are easily found.

Gene bank stocks that are selected should be screened for desirable characteristics.

Organic trials of these gene bank stocks based on primary selection can lead to the formation of suitable foundation stock.

\section{Simulating plant breeding programmes}

To obtain a good understanding of organic plant breeding, breeders should follow courses in organic agriculture.

Collaboration between individual breeders, breeding companies and organic farmers is must.

Participatory plant breeding approach should be followed.

Organic plant breeding is confined to specific breeding techniques and in general those crossing methods that do not lead to breakage of reproductive barriers species and selection methods that are based on individual plant performance i.e. backcrossing, mass and individual selection, selection via DNA markers, hybrid cultivars, meristem culture, intraspecific crossing. On the other hand technologies interfering at DNA level are 
regarded as incompatible. Participatory plant breeding and evolutionary breeding are regarded as suitable breeding methods for organic farming.

\section{References}

Baars T. 1998. Modern solutions for mixed systems in organic farming. In: H. van.

Bauer D. 1998. Harmonie, internal publication. Dottenfelderhof.

De Waart S. 1998. Voeding Biologisch: goed, beter, best/Biologische en gangbare groenten en fruit vergeleken: een overzicht. Louis Bolk Instituut, Driebergen.

Hardon, J., and W De Boef. 1993. In: De Boef, W., K. Amanor and K. Wellard. Cultivating Knowledge, genetic diversity, farmer experimentation and crop research. IT Publications.
Haselsmans, M. 1998. De plant als machine. NRC Handelsblad 20-1-1998, Rotterdam.

Keulen (ed.), 1998. Mixed farming systems in Europe. AP Minderhoudhoeve-reeks nr 2 (1998). Wageningen Agricultural University.

Muller, K.J. 1998. Erweiternde Kriterien fur die Zuchtung von sommerspeisegersten in Organische Landbau, Schriftenreihe institute fur organische Landbau, Verlag Dr. Koster, Berlin.

Scheller, E. 1988. Die Stickstoffversorgung der Pflanzen aus dem Stickstoffwechsel des bordens. Ein Beitrag zu einer Pflanzenernahrungslehre des Organischen Landbaus. Verlag J. Margraf Weikersheim.

Van der Burgt, Baars GT and Nauta W. 1999. Koppelbedrijven (in progress).

\section{How to cite this article:}

Shailja Sharma and Sanchit Thakur. 2018. Breeding Crops for Organic Agriculture: A Review. Int.J.Curr.Microbiol.App.Sci. 7(11): 965-971. doi: https://doi.org/10.20546/ijcmas.2018.711.112 